\title{
Chapter 15 \\ Blauzone Rheintal: A Regional Planning \\ Instrument for Future-Oriented Flood \\ Management in a Dynamic Risk \\ Environment
}

\author{
Lukas Löschner, Walter Seher, Ralf Nordbeck and Manfred Kopf
}

This chapter explores the case of a regulatory spatial planning instrument for flood risk management (FRM). The so-called "Blauzone Rheintal", a regional plan designating large-scale areas for flood retention and flood runoff in the Austrian Rhine Valley, was issued in 2013 by the Vorarlberg state government to secure flood hazard areas and mitigate future increases in flood risk. The selected case highlights the potential for spatial planning to support nature-based solutions (NBS) in FRM, particularly to secure land resources for the implementation of (land-intensive) flood retention measures. Based on a document analysis and qualitative interviews with the leading experts of the "Blauzone Rheintal" and with planning authorities in the Swiss canton St. Gallen, this contribution unravels the processes leading up to the final spatial plan, including the cross-sectoral and multilevel interactions that balanced the conflicting (land use) interests in the study area. Given the long-term dimension of

L. Löschner $(\bowtie) \cdot$ W. Seher

Institute of Spatial Planning, Environmental Planning and Land Rearrangement (IRUB), Vienna, Austria

e-mail: lukas.loeschner@boku.ac.at

W. Seher

e-mail: walter.seher@boku.ac.at

Department of Landscape, Spatial and Infrastructure Sciences (RALI), Vienna, Austria

L. Löschner · W. Seher · R. Nordbeck

University of Natural Resources and Life Sciences Vienna (BOKU), Vienna, Austria

e-mail: ralf.nordbeck@boku.ac.at

R. Nordbeck

Institute of Forest, Environmental, and Natural Resource Policy (InFER), Vienna, Austria

Department of Economics and Social Sciences (WiSo), Vienna, Austria

M. Kopf

Spatial Planning Department, State Government of Vorarlberg, Bregenz, Austria

e-mail: manfred.kopf@ vorarlberg.at

T. Hartmann et al. (eds.), Nature-Based Flood Risk Management on Private Land, https://doi.org/10.1007/978-3-030-23842-1_15 
many NBS, this contribution, moreover, discusses the apparent contradiction between static planning instruments and the need for adaptive, forward-looking FRM.

\section{Introduction}

Due to the concentration of inhabitants, settlements and economic activities in valleys, alpine areas are particularly susceptible to the impacts of natural hazards (Petraschek and Kienholz 2003; Fuchs et al. 2015). Since the mid-1990s, areas north of the alpine ridge have experienced a series of devastating flood events (1999, 2002, 2005 and 2013). Heavy losses, especially in densely populated alpine valleys, made evident the limits of traditional, defence-oriented flood policies and highlighted the need for more integrated approaches to FRM based on a portfolio of structural and non-structural measures (BMLFUW 2009).

A fundamental principle in the nascent policy paradigm is to "make space for water" (Warner et al. 2012). Across Europe, flood managers are increasingly reconnecting floodplains and providing more room for flood runoff and water retention to alleviate flood risks as well as to enhance the ecological and recreational values of riverscapes (Samuels et al. 2006; Klijn et al. 2008). Especially in topographically confined alpine regions, however, land is a limiting factor for the implementation of non-structural flood risk reduction measures. In these areas, spatial planning is of particular relevance to better allocate space to competing demands (Hartmann 2011).

This chapter explores the case of a regulatory spatial planning instrument for FRM. The so-called "Blauzone Rheintal", a regional plan designating large-scale areas for flood retention and flood runoff in the Austrian Rhine Valley, was issued in 2013 by the Vorarlberg state government to secure flood hazard areas and mitigate future increases in flood risk (State Government of Vorarlberg 2013). The selected case highlights the potential for spatial planning to support NBS in FRM, particularly to secure land resources for the implementation of land-intensive flood retention measures. Based on a review of policy documents in water management and spatial planning as well as four semi-structured interviews with the leading experts of the "Blauzone Rheintal", the case study unravels the process leading up to the final spatial plan, including the cross-sectoral interactions and the engagement of stakeholder groups to balance conflicting land use interests in the study area. Given the long-term dimension of many NBS, this contribution moreover discusses the apparent contradiction between static planning instruments and the need for adaptive, forward-looking FRM.

The chapter is organized as follows: the following section briefly outlines the geographic and institutional context of the "Blauzone Rheintal"; the section thereafter provides a detailed description of the planning instrument and the associated restrictions in land use and property rights; the subsequent section traces the policy process leading up to the spatial plan, including intersectoral coordination between water management and spatial planning and the involvement of different stakeholder groups; the final section discusses the relation of spatial planning and NBS and draws 
conclusions regarding the possibility of replicating and scaling-up the "Blauzone" in other flood-prone regions.

\section{The Rhine Valley: A Dynamic and Vulnerable Region in the Heart of Europe}

The Rhine Valley is an alpine valley in Central Europe that extends over $90 \mathrm{~km}$ along the Rhine from the source of the Rhine in Switzerland via Liechtenstein to Austria and Germany. The lower part of the Rhine Valley, separated by the Rhine into Austrian and Swiss areas, forms a wide basin ranging from the alpine ridge to the Bodensee (see Fig. 15.1).

Given its favourable geographic location and topographic conditions for agricultural production, this part of the Rhine Valley is a historical settlement area that today ranks as one of the most dynamic regions in Central Europe. In particular, the Austrian side of the Rhine Valley (Vorarlberger Rheintal) is experiencing strong settlement growth and economic development. Since 2006, the residential population has increased by $8.5 \%$ (to approximately 260,000 , or two thirds of the total population of Vorarlberg), and it is expected that the bulk of the province's future population growth (+16\% until 2050) will be concentrated in the Rhine Valley (State

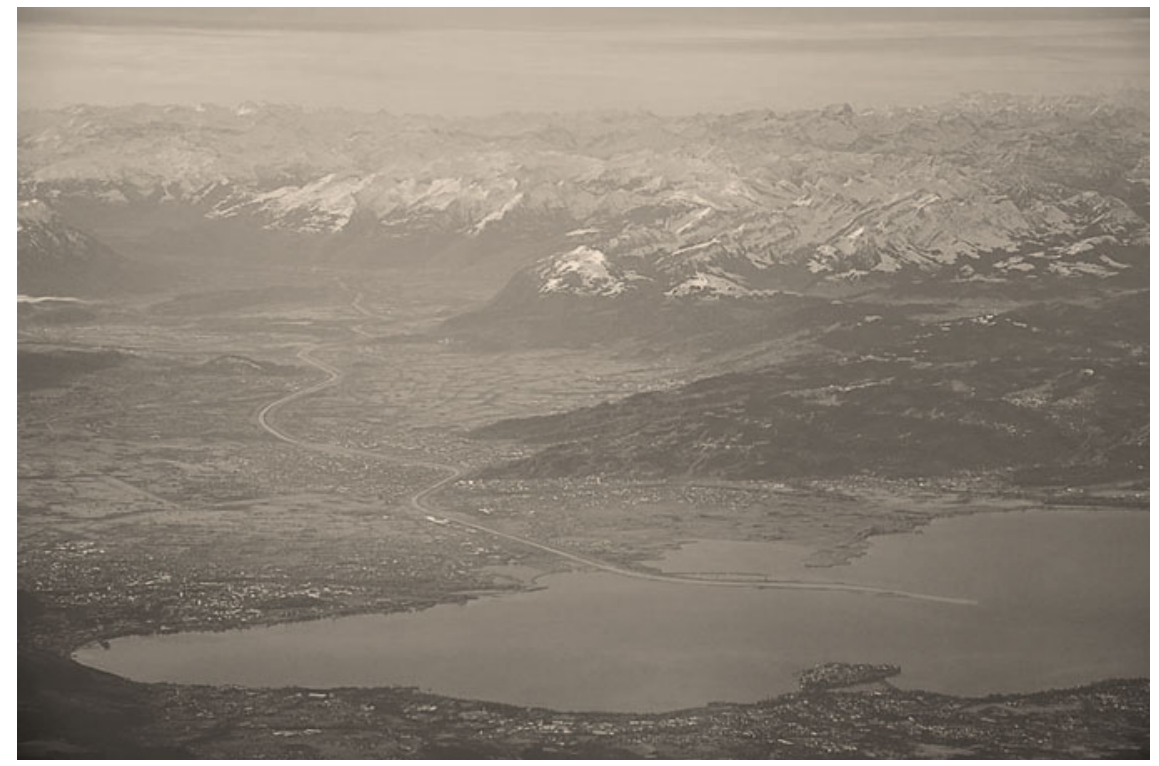

Fig. 15.1 View of the Rhine Valley with the Rhine outlet in the Bodensee and the Alps in the background. The Rhine forms the border between the Austrian part (left) and the Swiss part of the Rhine Valley [adapted from Krapf 2012; Wikipedia/Creative Commons] 
Government of Vorarlberg 2016a). This also reflects the region's strong economic relevance: As one of the Austria's leading manufacturing regions, the Rhine Valley accounts for more than $70 \%$ of economic production in Vorarlberg (WKO 2017).

Due to the concentration of vulnerable land uses, the region is at a high risk of flooding (BfG 2015; BMLFUW 2015). Currently, areas along the alpine part of the Rhine (Alpenrhein) is protected against the impacts of floods with a 100-year return period (discharge of $3.100 \mathrm{~m}^{3} / \mathrm{s}$ ), but simulations show that low-probability events (i.e., floods with a 300-year return period) would produce economic losses of around EUR 2.7 billion in Austria and EUR 2.07 billion in Switzerland (IRR 2017). To reduce the risk resulting from such an extreme flooding scenario, in 2005, the state governments of Vorarlberg, St. Gallen $(\mathrm{CH})$, Graubünden $(\mathrm{CH})$ and Liechtenstein initiated the transnational flood protection program "Rhesi" with the principal aim of raising the flood protection standard to $4.300 \mathrm{~m}^{3} / \mathrm{s}$ (i.e., the 300 -year discharge level), providing emergency retention areas and preventing uncontrolled dam breaches (IRR 2017).

The transnational character of the Rhesi project, however, is not matched by a common regulatory planning approach because spatial planning is widely regarded as a national task. In Austria, the spatial planning system is a comprehensive system arranged in a hierarchy, where the states are in charge of legislation and policymaking. The implementation of spatial planning is divided between the states and the municipalities, and the states are responsible for planning issues of regional importance. Local planning issues are controlled by the municipalities. In spatial planning practice, the local planning level (where the local land use plan is the most important instrument) is by far more relevant than the regional level. In comparison to other federally organized countries such as Germany or Switzerland, regional planning in Austria generally has a weak position. Due to the strong constitutional and political autonomy of Austrian municipalities, state governments have limited scope to interfere in municipal land use planning through regulatory instruments (Marik 2005).

The comparably low importance ascribed to regional planning applies particularly to flood-related spatial planning. With the exception of the "Blauzone" directive, Austrian spatial planning laws to date provide no legal obligations concerning direct flood-related zoning in regional planning, notwithstanding the wide availability of flood hazard information on a regional scale. By preserving open areas for flood retention and higher discharge levels and securing areas for future flood control measures, the spatial plan "Blauzone Rheintal" supports the implementation of the Rhesi project. This underpins the unique position of the Blauzone, giving this approach a role model function in Austrian spatial planning. The Blauzone also stands out in a cross-border perspective as comparable regulatory plans are missing on the Swiss side of the Rhine (Canton St. Gallen), despite a strong role of the cantonal level in spatial planning. Planning authorities in St. Gallen, however, highlight, that the cantonal structure plan (amended in 2017) legally defines the long-term settlement boundaries to prevent urban sprawl into agricultural land and thus preserves potential retention areas for emergency flood relief (Interview 4). 


\section{Blauzone Rheintal: A Regional Plan to Secure Large-Scale Flood Areas}

In 2005, Alpine regions in Austria and Switzerland suffered a major flood event. Vorarlberg, the westernmost province in Austria, was particularly affected, as some regions experienced the highest discharge levels in more than a century. Total damages to households, businesses, infrastructure, etc., amounted to more than EUR 180 million, making it the costliest natural disaster in Vorarlberg to date (State Government of Vorarlberg 2015). The majority of the flood damage was recorded in the province's alpine valleys, whereas the densely populated Rhine Valley with its concentration of economic assets was affected only to a limited extent. In the ten years following the seminal flood events (2005-2015), more than EUR 300 million was invested in flood protection, and an additional EUR 200 million has been provided until 2020 (State Government of Vorarlberg 2016b). Many of these flood protection measures were implemented or are planned in areas with strong settlement pressure, such as the Rhine Valley.

One of the key challenges for flood policy makers following the flood events in 2005 was providing space for flood alleviation measures and preventing urban sprawl into potential hazard areas. Faced with a lack of appropriate regulatory instruments to secure large-scale areas for flood protection measures, state officials in water management and spatial planning engaged in an intersectoral coordination process to identify and delineate suitable areas. In 2013, following another large flood event, the Vorarlberg state government issued the "Blauzone Rheintal", a legally binding regional spatial plan that designates flood runoff and flood retention areas along the Rhine and its tributaries (see Fig. 15.2). The planning instrument pursues the following aims (State Government of Vorarlberg 2013):

- Protect settlement areas: Existing settlement areas (i.e., built areas as well areas zoned as building land in the local land use plans) are protected against flooding. To minimize the further increase in damage potential, zoning for building land in the designated flood hazard areas is severely restricted.

- Preserve open areas for flood retention and flood discharge: To reduce flood peaks, existing and potential flood retention areas are kept free of building development. These areas particularly include agricultural and forest areas with low damage potential, which may also be temporarily flooded in extreme events, as when there is a need to accommodate storm water to prevent a dike breach.

- Secure areas for future flood control measures: Areas with low damage potential are secured for future flood control measures in order to preserve long-term FRM options.

Covering an area of 5.400 ha in twenty-two municipalities on the Austrian side of the Rhine Valley, the "Blauzone" is overwhelmingly (ca. 90\%) located in the so-called "Grünzone", which was established in 1977 to preserve open spaces and agricultural areas of regional importance in the Rhine Valley. Accordingly, the "Blauzone" predominately includes areas with low damage potential, such as agricultural 


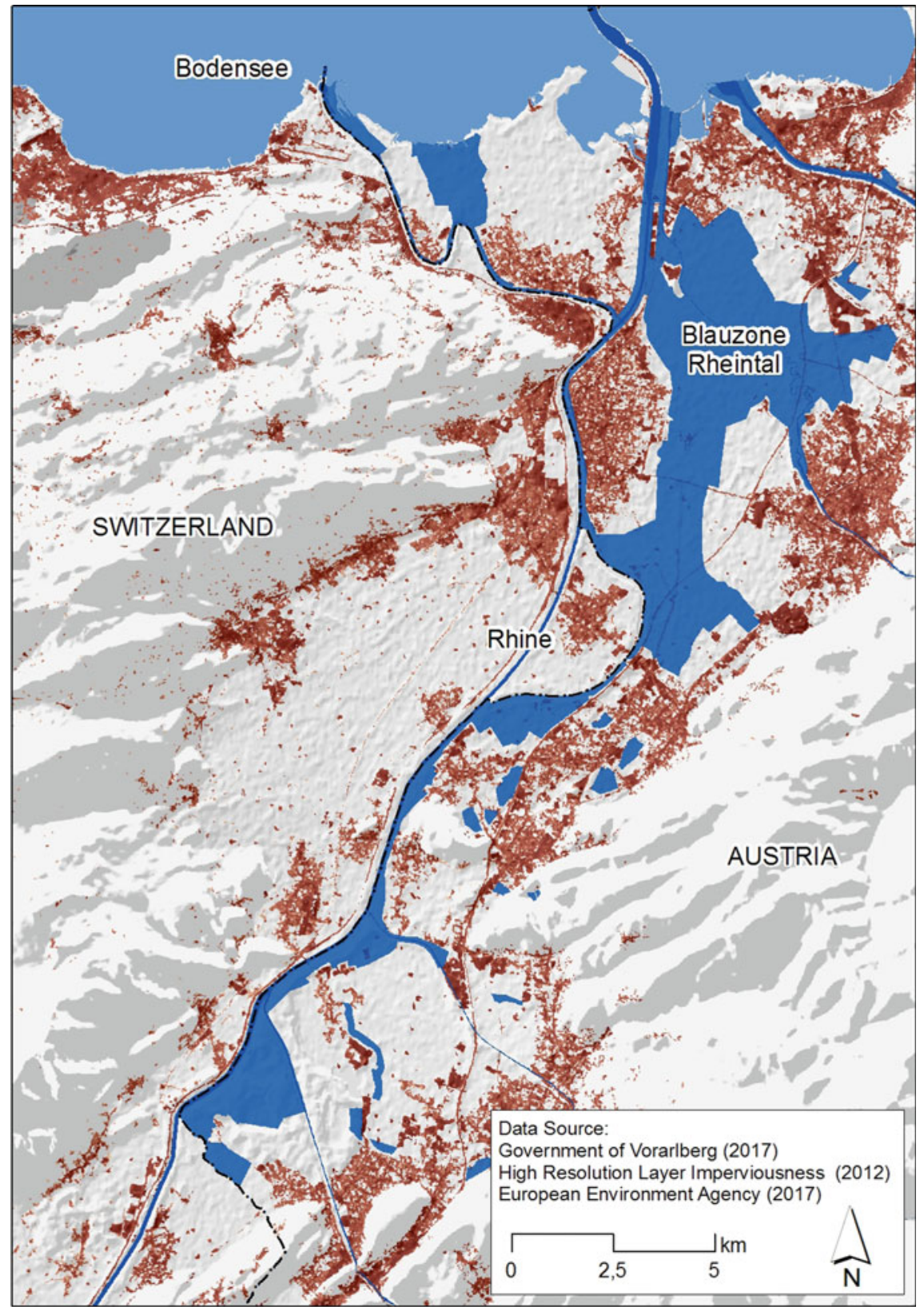

Fig. 15.2 Spatial extent of the Blauzone Rheintal 
or forestland. Highly vulnerable areas, meaning developed areas, as well as land zoned for building were specifically excluded from the spatial plan.

Given its character as a regulatory planning instrument, the "Blauzone" was issued as a legally binding directive, which obliges the affected municipalities to amend their local land use plans and (re)zone areas located within the "Blauzone" as so-called open space reserve areas. This means that no development is permitted in those reserve areas with the exception of enlarging existing agricultural facilities (State Government of Vorarlberg 2013).

\section{Interests and Interactions: The Process Leading Up to the Regional Plan}

Plans to establish a set of retention areas in the Rhine valley first emerged in 2005 from discussions in the context of the Development Concept Rhine Valley (IRKA and IRR 2005). The development concept was adopted in December 2005 and introduced the idea of establishing runoff areas for extreme events along the Rhine. It proposed the formulation of overflow sections and runoff areas for the region and urged that these runoff areas be secured by spatial planning instruments. In May 2008, the Vorarlberg state government adopted various measures to coordinate spatial planning and flood protection in order to improve the spatial prerequisites for FRM and to secure runoff and retention areas as well as areas for future flood control measures. One of the suggested measures was the establishment of so-called "Blue Zones".

In the following years, the state authorities, in particular the departments of spatial planning and water management, continued to pursue the idea of "Blue Zones" (Frei and Kopf 2011). However, the final push to realize the regional plan came from the extreme flood event that occurred in June 2013 (Interview 1, Interview 2). Six months later, the regulation for the Blauzone Rheintal was passed by Vorarlberg's state parliament (State Government of Vorarlberg 2013). Subsequently, the regional plan was made available online via the state's geographic information portal (VOGIS).

During the planning process of the Blauzone, different user interests had to be taken into account and weighed to ensure that the public interest, as a higher-ranking goal of spatial planning, is served as well as possible. To accommodate the various interest groups, two elements of the planning process are important and will be analysed in greater detail: the intersectoral coordination between the spatial planning and water management authorities and the engagement of different stakeholder groups, particularly the municipalities, organized interest groups and affected landowners. 


\section{Intersectoral Coordination: The New Paradigm of Integrated Flood Risk Management in Action}

Sectoral integration is defined as the integration of different public policy domains and includes the integration of public, private, and voluntary sector activities (Kidd 2007). Therefore, sectoral integration may be understood as a combination of sectoral policy integration and sectoral actors' integration. In practice, integration often refers to an approach to strengthen the linkages between places, the cooperation between sectors, or the interconnections among policies (Ran and Nedovic-Budic 2016). More integrated sectoral policies can encourage greater understanding of the effects of policies on other sectors. It can further help to promote synergies and consistency between policies in different sectors, improve the achievement of cross-cutting goals or objectives, and promote innovation in policy development and implementation (Stead and Meijers 2009).

Intersectoral coordination between flood management and spatial planning was identified as a major concern in Austria after the extreme flood events in 2002 and 2005. Several proposals have been made, inter alia, to create legally binding provisions for floodplains and hazard zones in spatial planning laws and building laws in order to prohibit the development of land that is important for flood runoff or retention (Habersack et al. 2009). Spatial planning is expected to contribute to flood mitigation mainly because it can influence the incidence of flooding and its consequential damage by regulating the locations of activities, types of land use, scales of development, and designs of physical structures (Ran and Nedovic-Budic 2016).

In response to the extreme flood events in 2005, policy makers in Vorarlberg formulated a strategy for integrated flood protection. The objective of the strategy is to minimize risks and improve the quality of overall flood protection. Based on the guiding principle of modern hydraulic engineering ("flood retention instead of flood acceleration"), the strategy specifically aims to preserve natural runoff areas, widen waterways and establish retention areas (State Government of Vorarlberg 2016b). To this end, the strategy highlights the need for better intersectoral coordination, particularly between water management and spatial planning, and defines spatial provisions as a strategic cornerstone for securing flood hazard areas and preventing the increase in potential damage in flood-prone areas.

The Blauzone Rheintal is a result of the strategic reorientation of the state's flood policy. It was developed on the basis of intersectoral coordination between the departments of spatial planning and water management and, thus, illustrates some of the challenges related to policy integration. Importantly, the Blauzone highlights that intersectoral policy-making is about balancing different policy interests. The spatial plan in its present form, in fact, represents a compromise between water management's sectoral demand for "more space for the river" and spatial planning's need to equally consider other public interests in the Rhine Valley, notably future opportunities for socio-economic development.

The intersectoral coordination processes leading up the delineation of the "Blauzone" may be characterized as a process of "spatial translation", which evolved 
around two issues: (i) data abstraction and harmonization and (ii) exclusion and contextualization. For one, the hydrological data and models for 300-year flood events and emergency runoff generated disconnected flooding areas, which could not be mapped into a single spatial plan. The data had to be transformed by the spatial planning authorities into a more coherent map of flood areas based on defining landscape and geographic features, such as roads, property lines or terrain edges (Interview 1). Second, the flood models had to be contextualized to facilitate implementation. All vulnerable land uses (i.e., all developed areas as well as land designated for building) were therefore eliminated from the flood models to minimize conflicts with landowners. Moreover, priority areas for future settlement development that were displayed in the spatial development plans were excluded to maintain socio-economic options for the municipalities (State Government of Vorarlberg 2013).

In summary, the integration of spatial planning with flood-risk management in the case of the Blauzone was based on three factors:

(i) Building communication channels between the departments and their representatives to develop a common mind-set based on collective knowledge and shared interests.

(ii) A coordinated management of information using geographic information systems as facilitators to support both spatial planning and flood-risk management.

(iii) A rational decision-making process that evaluated policy alternatives from both perspectives: the flood-risk management perspective as well as the planning and development perspective.

\section{Information and Negotiation: Engaging Municipalities and Landowners}

The "Blauzone" directive obliges a total of twenty-two municipalities to implement the 'Blue Zones' in local land use plans by (re)zoning areas as open space. To ensure a broad acceptance of the planning instrument, representatives of all affected municipalities as well as representatives of agricultural and commercial associations were informed about the spatial provisions in a series of events by staff from both the water management and the spatial planning authorities (Frei and Kopf 2011; Kopf 2016). Landowners and affected parties had the opportunity to comment on the proposed plans in a consultation procedure (Kopf 2016). As the spatial provisions overwhelmingly concern agricultural land, farmers and the Chamber of Agriculture in particular were strategic partners for the implementation of the regional plan.

On the one side, with the political backing of the state government, it was necessary to convince the representatives of the affected municipalities of the need to preserve open areas for flood retention and flood runoff and to secure areas for flood protection measures in the future. State representatives conducted information events with the local representatives of the 22 affected municipalities. This process of informing and convincing the communities was described as time-consuming and challenging 
(Interview 2), and there were, of course, mayors who were more accessible from the beginning and others who were less so. Nevertheless, reservations on the part of the local representatives remained rather low, mainly because settlement areas and areas designated as building land were excluded from the "Blauzone" and the municipalities' development opportunities were hardly limited. On the other side, more work had to be performed to convince the affected landowners (in particular farmers) who acknowledged, on the one hand, that the open areas would be even more stringently protected by the "Blauzone" but, on the other hand, feared a reduction in land value and a restriction of future farm extensions (Interview 1, Interview 2). These reservations were countered by the legal possibility of attaching further buildings to an existing farmhouse and the guarantee that the "Blauzone" would not restrict the cultivation of agricultural land.

In total, 96 written appeals were made during the review and consultation process. The inputs included various, often overlapping aspects, which can be assigned to the following thematic priorities (Kopf 2016): agriculture (46\%), property (21\%), business development (9\%), water management $(7 \%)$ and other aspects (17\%). Based on these submissions, further information and discussions occurred. In the end, some adjustments to the original plan were made, and approximately $2 \%$ (112 hectares) of the proposed area was further excluded, taking into account conflicting user interests. The state authorities regarded these minor changes as very justifiable (Interview 1).

\section{Spatial Planning and Nature-Based Solutions in Flood Risk Management}

The implementation process of the Blauzone Rheintal and the associated infringements of private property rights and future land-use opportunities illustrate the "growing importance of land resources in flood risk management" (Seher and Löschner 2017). By designating large-scale flood runoff and flood retention areas, the spatial plan regulates which land uses are compatible with the overall aim of providing more space for the Rhine and mitigating flood damage potential. In itself, regional planning instruments, such as the example discussed in this contribution, do not qualify as NBS, which are understood as "actions which are inspired by, supported by or copied from nature" (EC 2015). However, by securing the necessary land resources for the implementation of NBS, such as using wetlands to create emergency flood capacities, reconnecting rivers with floodplains or relocating dikes to make more space for flood storage, regulatory planning instruments provide important leverages for mitigating the impacts of floods and other natural hazards (EEA 2015).

Like NBS in general, the Blauzone Rheintal results in multiple co-benefits (EC 2015). Apart from reducing the risk of river flooding in the Rhine Valley, the spatial plan provides the following core benefits for the region:

- Preventing urban sprawl: By obliging municipalities to amend their local land use plans and (re)zone areas located within the "Blauzone", the planning instrument 
limits the encroachment of settlements into open space areas. Given the strong socio-economic growth in this part of the Rhine Valley, this supports planning strategies aimed at inner urban development.

- Securing agricultural production: The Blauzone Rheintal prevents settlement pressures on existing agricultural areas and secures productive soils along the Rhine for farming and agriculture. Although the "Blauzone" limits opportunities to expand agricultural buildings and financial profits from possible rezoning, the instrument only marginally interferes with existing land use rights and thus preserves future options for agricultural production.

- Preserving multifunctional open space: The "Blauzone" overwhelmingly coincides with the "Grünzone". It therefore, reinforces the legitimacy of an existing planning instrument and implicitly supports its fundamental goals, namely, the preservation of landscapes, biodiversity and local recreation areas.

The Blauzone Rheintal creates these multiple co-benefits in the Rhine Valley by assigning (long-term) land use and property rights (Needham and Hartmann 2016). Like other regulatory planning instruments, the spatial plan at first sight does not seem compatible with the "need for flexibility emanating from changing flood risk" (Tempels and Hartmann 2014) due to the "dynamic behaviour of floodplains as humanwater systems" (Di Baldassarre et al. 2013). However, the "Blauzone" is explicitly designed as a rather flexible instrument in order to "adapt to changing future conditions" such as climate-induced changes in the flood hydrograph or to provide room for land development as a consequence of reduced flood hazards (Government of Vorarlberg 2013). By securing large-scale areas for future flood control measures (such as the relocation of the Rhine outlet into the Bodensee), the Blauzone Rheintal preserves space for manoeuvre to meet the long-term commitments associated with many measures in FRM (Interview 3). This forward-looking approach is best illustrated by the words of a leading architect of the Blauzone Rheintal: "Now we have secured these retention areas at least for the next generation. And if we had not done so, we would have seen buildings erected in these areas and emergency relief corridors would have been gone" (Interview 2).

In this regard, the Blauzone Rheintal is an example of a planning instrument that keeps options open for the future and prevents lock-in situations, which arise from floodplain development (Restemeyer et al. 2016). By preserving the flexibility of the system, the spatial plan also constitutes a reversible strategy in floodplain development (Hallegatte 2009): once flood protection measures (such as controlled retention basins) are implemented, policy makers may opt to reduce the extent of the "Blauzone" to again provide space for settlement development (Interview 2, Interview 3).

Despite the benefits of the planning instrument for adaptive, future-oriented FRM, the Blauzone Rheintal remains an isolated example of a regional approach to floodrelated planning in Austria. As other countries have a more favourable institutional context for the implementation of risk reduction and FRM strategies in regional plans (Böhm et al. 2004), the Blauzone Rheintal is a planning instrument that is principally suitable for replication and upscaling in other flood-prone regions. 
There are, however, some noteworthy contextual conditions of the Blauzone Rheintal, which should be taken into consideration in the case of adoption in other areas. First, the Blauzone Rheintal was developed on the basis of an existing, truly visionary spatial plan ("Grünzone"), which secured open areas and agricultural land as early as the late 1970s. It is highly doubtful whether the "Blauzone" could have been realized without the "Grünzone". Second, the spatial plan is part of large, transnational flood protection program (Rhesi). Its aims to provide emergency retention areas and secure areas for future flood control measures are facilitated by its being embedded in regional FRM. Third, due to the concentration of risk elements and the strong socio-economic growth in the Rhine Valley, settlement pressures necessitated a coordinated response at a larger scale to prevent further increases in damage potential. Finally, the planning instrument is the result of intensive crosssectoral integration efforts by the state government departments of spatial planning and water management and a participatory process engaging various stakeholders, particularly the 22 municipalities and private landowners.

Acknowledgements We thank the Austrian Climate and Energy Fund for financing the projects Flood-Adapt (grant number: KR14AC7K11809) and RegioFlood (grant number: KR15AC8K12549) that led to the present book chapter.

Open access of this chapter is funded by COST Action No. CA16209 Natural flood retention on private land, LAND4FLOOD (www.land4flood.eu), supported by COST (European Cooperation in Science and Technology).

\section{References}

BfG (ed) (2015) Rheinatlas 2015. German Federal Institute of Hydrology (Bundesanstalt für Gewässerkunde-BfG), Koblenz

BMLFUW (ed) (2009) FloodRisk II. Vertiefung und Vernetzung zukunftsweisender Umsetzungsstrategien zum integrierten Hochwassermanagement. Synthesebericht. Bundesministerium für Land- und Forstwirtschaft, Umwelt und Wasserwirtschaft, Wien

BMLFUW (ed) (2015) Hochwasserrisikomanagementplan 2015. Risikogebiet: Alpenrhein 8001. Bundesministerium für Land- und Forstwirtschaft, Umwelt und Wasserwirtschaft, Wien

Böhm HR, Haupter B, Heiland P, Dapp K (2004) Implementation of flood risk management measures into spatial plans and policies. River Res Appl 20:255-267. https://doi.org/10.1002/rra.776

Di Baldassarre G, Kooy M, Kemerink JS, Brandimarte L (2013) Towards understanding the dynamic behaviour of floodplains as human-water systems. Hydrol Earth Syst Sci 17:3235-3244. https:// doi.org/10.5194/hess-17-3235-2013

EC (ed) (2015) Towards an EU Research and Innovation policy agenda for Nature-Based Solutions $\&$ Re-Naturing Cities. Final report of the Horizon 2020 Expert Group on "Nature-Based Solutions and Re-Naturing Cities." European Commission, Brussels

EEA (ed) (2015) Exploring nature-based solutions. The role of green infrastructure in mitigating the impacts of weather- and climate change-related natural hazards. EEA technical report no 12/2015, European Environment Agency, Luxemburg

Frei R, Kopf M (2011) Blaue Zonen in Vorarlberg. Vorum-Forum Für Raumplan Reg Vorarlb 5-6

Fuchs S, Keiler M, Zischg A (2015) A spatiotemporal multi-hazard exposure assessment based on property data. Nat Hazards Earth Syst Sci 15:2127-2142. https://doi.org/10.5194/nhess-152127-2015 
Government of Vorarlberg (2013) Blauzone Rheintal. Verordnung der Vorarlberger Landesregierung über die Festlegung von überörtlichen Freiflächen zum Schutz vor Hochwasser im Rheintal, Bregenz

Habersack H, Bürgel J, Kanonier A (2009) FloodRisk II: further steps for future implementation strategies towards an integrated flood risk management. English short report, Bundesministerium für Land- und Forstwirtschaft, Umwelt und Wasserwirtschaft, Wien

Hallegatte S (2009) Strategies to adapt to an uncertain climate change. Glob Environ Change 19:240-247. https://doi.org/10.1016/j.gloenvcha.2008.12.003

Hartmann T (2011) Contesting land policies for space for rivers-rational, viable, and clumsy floodplain management. J Flood Risk Manag 4:165-175. https://doi.org/10.1111/j.1753-318X. 2011.01101.x

IRKA, IRR (eds) (2005) Entwicklungskonzept Alpenrhein-Kurzbericht. Internationale Regierungskommission Alpenrhein und Internationale Rheinregulierung

IRR (ed) (2017) Rhesi-Rhein, Erholung und Sicherheit. Internationale Rheinregulierug

Kidd S (2007) Towards a framework of integration in spatial planning: an exploration from a health perspective. Plan Theory Pract 8:161-181. https://doi.org/10.1080/14649350701324367

Klijn F, Samuels P, Os AV (2008) Towards flood risk management in the EU: state of affairs with examples from various European countries. Int J River Basin Manag 6:307-321. https://doi.org/ $10.1080 / 15715124.2008 .9635358$

Kopf M (2016) Strategie im Umgang mit Hochwasser: Blauzone Rheintal. Raumdialog Mag für Raumplan Reg Niederösterr 3(2016):20-21

Marik S (2005) Raumordnung in der Kommunalpolitik. Akteure-Entscheidungen-Umsetzung. Dissertation, Universität Wien, Fakultät Geowissenschaften, Geographie und Astronomie

Needham B, Hartmann T (2016) Planning by law and property rights reconsidered. Routledge, London

Petraschek A, Kienholz H (2003) Hazard assessment and mapping of mountain risks-example of Switzerland. In: Rickenmann D, Chen C (eds) Debris flow hazard mitigation. Millpress, Rotterdam, pp 25-38

Ran J, Nedovic-Budic Z (2016) Integrating spatial planning and flood risk management: a new conceptual framework for the spatially integrated policy infrastructure. Comput Environ Urban Syst 57:68-79. https://doi.org/10.1016/j.compenvurbsys.2016.01.008

Restemeyer B, van den Brink M, Woltjer J (2016) Between adaptability and the urge to control: making long-term water policies in the Netherlands. J Environ Plan Manag 60:920-940. https:// doi.org/10.1080/09640568.2016.1189403

Samuels P, Klijn F, Dijkman J (2006) An analysis of the current practice of policies on river flood risk management in different countries. Irrig Drain 55:141-150. https://doi.org/10.1002/ird.257

Seher W, Löschner L (2017) Anticipatory flood risk management—challenges for land policy. In: Hepperle E, Dixon-Gough R, Mansberger R et al (eds) Land ownership and land use development. The integration of past, present, and future in spatial planning and land management policies. vdf Hochschulverlag AG, Zurich

State Government of Vorarlberg (2015) 10 Jahre danach. Jahrhundert-Hochwasser 2005. Maßnahmen und Strategie, Bregenz

State Government of Vorarlberg (2016a) Regionale Bevölkerungsprognose 2015 bis 2050, Bregenz

State Government of Vorarlberg (2016b) Integaler Hochwasserschutz. Risiken erkennen, vermindern, akzeptieren, Bregenz

Stead D, Meijers E (2009) Spatial planning and policy integration: concepts, facilitators and inhibitors. Plan Theory Pract 10:317-332. https://doi.org/10.1080/14649350903229752

Tempels B, Hartmann T (2014) A co-evolving frontier between land and water: dilemmas of flexibility versus robustness in flood risk management. Water Int 39:872-883. https://doi.org/10.1080/ 02508060.2014.958797

Warner JF, van Buuren A, Edelenbos J (2012) Making space for the river. IWA Publishing, London/New York 
WKO (2017) Vorarlberger Regionen-Arbeitsplätze nach Wirtschaftssektoren 2012. Wirtschaftskammer Vorarlberg, Bregenz

Dr. Lukas Löschner has an academic background in Political Science and Landscape Planning and holds a Ph.D. in Spatial Planning. His main field of research is natural hazard risk management, which he explores in a combination of political science and planning approaches. He currently conducts research on the following topics: spatial adaptation to flooding, policy coordination in FRM, flood risk governance, and flood storage compensation.

Ass. Prof. Dr. Walter Seher holds a masters degree in Civil Engineering and Water Management and a Ph.D. from BOKU University. His key qualifications in research and teaching include spatial planning in natural hazard risk management and climate change adaptation, land rearrangement and land policy. Current research activities are focused on flood risk governance, spatial adaptation to flash floods and land policy in natural hazard risk management.

Dr. Ralf Nordbeck is a post-doc researcher at the University of Natural Resources and Life Sciences, Vienna (BOKU), and holds a Ph.D. in Political Science. Since 2005 he has worked and lectured at BOKU in the fields of environmental and natural resource policies. His current research interests are the comparative analysis of environmental policies, new modes of environmental governance, flood risk governance, and intersectoral and multi-level coordination issues.

Dipl.-Ing. Manfred Kopf studied Landscape Ecology and Landscape Design at BOKU University and expanded his spatial planning knowledge in postgraduate studies at ETH Zurich. As head of the division for Regional Spatial Planning in the State Government of Vorarlberg, he is primarily involved with the implementation of spatial planning policies for settlement development and the conservation of open space.

Open Access This chapter is licensed under the terms of the Creative Commons Attribution 4.0 International License (http://creativecommons.org/licenses/by/4.0/), which permits use, sharing, adaptation, distribution and reproduction in any medium or format, as long as you give appropriate credit to the original author(s) and the source, provide a link to the Creative Commons license and indicate if changes were made.

The images or other third party material in this chapter are included in the chapter's Creative Commons license, unless indicated otherwise in a credit line to the material. If material is not included in the chapter's Creative Commons license and your intended use is not permitted by statutory regulation or exceeds the permitted use, you will need to obtain permission directly from the copyright holder.

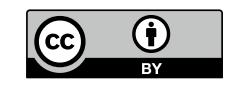

